DOI 10.4467/12332135KRA.21.014.14693

\title{
Nowa strona internetowa „Krakowskiego Rocznika Archiwalnego” i publikacja czasopisma na Portalu Czasopism Naukowych
}

Mijający rok upłynął pod znakiem intensyfikacji działań związanych z poprawą dostępności „Krakowskiego Rocznika Archiwalnego” w internecie. W lipcu zakończyły się trwające ponad półtora roku prace nad zaprojektowaniem, przygotowaniem treści i publikacją nowej strony internetowej czasopisma, a w maju pierwszy z tomów Rocznika został udostępniony przez Archiwum Narodowe w Krakowie na Portalu Czasopism Naukowych.

Zamysł przygotowania nowego serwisu internetowego „Krakowskiego Rocznika Archiwalnego" pojawił się w 2019 r. Dotychczasowa strona Rocznika ${ }^{1}$ była mało funkcjonalna i nieatrakcyjna wizualnie, a przede wszystkim mocno przestarzała pod względem technologicznym (jako strona statyczna kodowana w języku HTML pozbawiona była systemu zarządzania treścią CMS i wymagała zwiększonych nakładów pracy w obsłudze i aktualizacji). Nie spełniała także wymogów dostępności cyfrowej określonych przepisami ${ }^{2}$. Z tego względu podjęta została decyzja o budowie nowej strony, która - co było założeniem projektu od samego początku - oferowałaby możliwość udostępniania online tomów „Krakowskiego Rocznika Archiwalnego”, do tej pory publikowanego na stronie Małopolskiej Biblioteki Cyfrowej, niedostępnego natomiast na stronie własnej Archiwum. Prace projektowo-koncepcyjne trwały wiosną i latem 2019 r. - ostatecznie sporządzono ${ }^{3}$ wstępne założenia do projektu graficznego nowego serwisu, jego struktury i zawartości oraz opracowano mapę strony. Celem nadrzędnym było przygotowanie przejrzystej, czytelnej i w pełni funkcjonalnej witryny internetowej, wzbogaconej o niedostępne w starej wersji strony treści, których adresatami będą zarówno wszyscy uczestnicy procesu wydawniczego (autorzy, recenzenci, członkowie zespołu redakcyjnego), jak też czytelnicy Rocznika. Przy projektowaniu konstrukcji serwisu (elementy menu, ilość podstron, nawigacja w obrębie strony itp.) i opracowywaniu jego zawartości kierowano się także kryteriami oceny czasopism naukowych w procesie ewaluacji prowadzonej w związku z aplikowaniem do referen-

${ }^{1}$ Prowadzona od 2012 r. pod adresem www.kra.archiwum.krakow.pl, a od 2014 r. - www.kra. ank.gov.pl, Kamila Follprecht, 25 lat „Krakowskiego Rocznika Archiwalnego”, [w:] Krakowski Rocznik Archiwalny. Spis zawartości tomów I-XXV (1995-2019), Kraków 2020, s. 8.

${ }^{2}$ Ustawa z dnia 4 kwietnia 2019 r. o dostępności cyfrowej stron internetowych i aplikacji mobilnych podmiotów publicznych (Dz.U. z 2019 r., poz. 848).

${ }^{3}$ Od samego początku realizacją przedsięwzięcia zajmowały się Anna Sokół i Aldona Warzecha (przy wsparciu Kamili Follprecht), wykonały one wszystkie prace związane z zaprojektowaniem i przygotowaniem do uruchomienia nowego serwisu. 
cyjnych baz danych ${ }^{4}$. Oczywiście nowa strona miała też spełniać standardy wytycznych dla dostępności internetowej WCAG (Web Content Accessibility Guidlines).

W październiku przeprowadzono postepowanie mające na celu wyłonienie wykonawcy strony i w listopadzie 2019 r. podpisano umowę z Brave New Sp. z o.o. z siedzibą w Krakowie. W kolejnych miesiącach, w ścisłym kontakcie z Archiwum, firma dopracowała i z powodzeniem wdrożyła w życie zamierzenia projektowe.

W efekcie w pierwszym kwartale 2020 r. strona została zainstalowana na docelowym serwerze, pod tymczasowym adresem umożliwiającym jej sprawdzenie. Dzięki temu dalsze prace prowadzone były na stronie opublikowanej (choć nieupublicznionej), co dało komfort jej testowania i przygotowania treści w środowisku produkcyjnym. Umożliwiło to choćby sprawdzenie dostępności witryny w walidatorach online oraz za pomocą sztandarowych wtyczek do przeglądarek internetowych, weryfikację responsywności strony, czy podgląd i korektę na bieżąco fraz kluczowych i opisów podstron mających wpływ na pozycjonowanie całego serwisu. W dalszej części roku przeprowadzono gruntowne testy strony (trzy kompleksowe i kilka dodatkowych dla wybranych funkcjonalności) i wdrożono poprawki. Jednocześnie pracowano nad nowymi treściami - dokonano wyboru grafik i ilustracji na stronę główną, zredagowano teksty przeznaczone do publikacji na wszystkich podstronach i zlecono ich tłumaczenie na język angielski. Opracowano też nowe ${ }^{5}$ wzory dokumentów dostępnych na stronie w formie załączników do pobrania - umów, oświadczeń i wytycznych dla autorów. Ponadto skompletowano pliki pdf dotychczas wydanych tomów „Krakowskiego Rocznika Archiwalnego” i przygotowano je do publikacji - dla każdego rocznika wyodrębniono strony redakcyjne i spisy treści oraz wygenerowano plik całego tomu i uzupełniono metadane dla wszystkich tych plików. Po zakończeniu testów i wdrożeniu poprawek przez Wykonawcę rozpoczęto wypełnianie serwisu przygotowanymi treściami. Była to czasochłonna praca, wymagająca bieżącej weryfikacji, choć zadanie z pewnością ułatwił intuicyjny system zarządzania treścią WordPressa, na którym strona została zbudowana.

Nowa witryna została opublikowana w lipcu 2021 r. pod dotychczasowym adresem www.kra.ank.gov.pl. Składa się ze strony głównej i 12 zasadniczych działów. Są to podstrony: „Aktualności”, „,Tomy online”, „O czasopiśmie”, „,Dla autorów”, „Procedura recenzowania”, „Zasady etyki publikacji”, „Dostęp i prawo autorskie”, „Recenzenci”, „Wykaz autorów”, „Rada Naukowa”, „Redakcja”, „Kontakt”. Dodatkowo publikowane są stałe

${ }^{4} \mathrm{~W}$ tym wypadku pomocne były opracowania zawierające wytyczne i porady na temat zawartości stron internetowych czasopism naukowych, np. Aneta Drabek, Indeksowanie czasopism w referencyjnych bazach danych, Poznań 2018, DOI: 10.6084/M9.FIGSHARE.5683972. Kierowano się też aktualnymi kryteriami selekcji periodyków przez bazy naukowe, m.in. Scopus, ERIH PLUS czy Web of Science. Wytyczne zawarte w ww. procedurach wskazują pośrednio na to, jakie powinny być elementy funkcjonalnej i klarownej strony internetowej czasopisma naukowego.

${ }^{5}$ Prace nad stroną prowadzone były równolegle i w ścisłym związku z pracami koncepcyjnymi nad zmianami (od t. 26 „Krakowskiego Rocznika Archiwalnego”) w samym Roczniku oraz przygotowywaniem tomów do udostepnienia na Portalu Czasopism Naukowych (zob. dalej). Redakcja zdecydowała m.in. o nadawaniu numerów DOI dla wszystkich publikowanych tekstów, zmianie układu strony tytułowej artykułów, wprowadzeniu do umów wydawniczych zapisów dotyczących modelu licencjonowania opartego na licencjach Creative Commons (CC-BY - uznanie autorstwa 4.0). Pozyskano także numer e-ISSN dla Rocznika. 
elementy typu deklaracja dostępności, polityka prywatności i plików cookies oraz zasady dotyczące ochrony danych osobowych. W działach zamieszczono wiadomości na temat Rocznika (cele, zakres i historia czasopisma, skład komitetu redakcyjnego oraz Rady Naukowej, wykazy dotychczasowych recenzentów i autorów) oraz informacje dotyczące zasad i przebiegu procesu wydawniczego (wskazówki dla autorów przygotowujących teksty do publikacji, opis przebiegu procedury recenzowania, wyszczególnienie zasad etycznych obowiązujących w czasopiśmie, przyjętego przez Rocznik systemu licencjonowania związanego z polityką otwartego dostępu, wzory dokumentów, m.in. umów licencyjnych $z$ autorami i formularza recenzji). Na nowej stronie udostępnione zostały także wszystkie dotychczas wydane tomy czasopisma. Można je pobrać w formacie pdf. Dla najnowszych roczników, oprócz opcji zapisania całego tomu, istnieje także możliwość pobrania wybranych artykułów, opatrzonych numerem DOI (Digital Object Identifier). W tym ostatnim przypadku następuje przekierowanie na stronę Rocznika na Portalu Czasopism Naukowych. Udostępniono także spis zawartości tomów Rocznika, corocznie aktualizowany. Dodatkowo w dziale „Aktualności” zamieszczane są informacje dotyczące wydarzeń związanych z Rocznikiem i bieżącego etapu prac wydawniczych. Witryna prowadzona jest w językach polskim i angielskim. Serwis został graficznie zaprojektowany w sposób przejrzysty i nowoczesny, posiada też udogodnienia dla użytkowników z niepełnosprawnościami (m.in. wersja kontrastowa, skiplinki, widoczny fokus nawigacji klawiszem tab, struktura nagłówkowa treści, teksty alternatywne dla ilustracji).

Równolegle z realizacją działań nad stworzeniem nowej strony internetowej „Krakowskiego Rocznika Archiwalnego" nawiązano współpracę z Wydawnictwem Uniwersytetu Jagiellońskiego w zakresie edycji i rozpowszechniania wersji elektronicznych czasopisma. Pod koniec marca 2021 r. została podpisana umowa określająca zasady publikacji Rocznika na Portalu Czasopism Naukowych www.ejournals.eu. Na stronie prezentowane są wersje cyfrowe pełnych numerów czasopism naukowych ${ }^{6}$.

W kwietniu i maju trwały prace nad przygotowaniem treści koniecznych do utworzenia zakładki Rocznika na portalu - zredagowano informacje na temat czasopisma i jego polityki wydawniczej oraz opracowano grafikę nagłówkową ${ }^{7}$. Przygotowano także do publikacji pliki t. 25 „Krakowskiego Rocznika Archiwalnego” (w podziale na strony redakcyjne, spisy treści, pojedyncze teksty - według norm obowiązujących na portalu). W maju materiały zostały opublikowane na nowo powstałej podstronie poświęconej Rocznikowi - https:// www.ejournals.eu/KRA, dostępnej w języku polskim i angielskim. Jednocześnie teksty zamieszczone $\mathrm{w}$ ww. tomie zostały opatrzone identyfikatorami $\mathrm{DOI}^{8}$. Na marginesie na-

${ }^{6}$ Aktualnie jest to 95 periodyków z dziedziny nauk humanistycznych, społecznych, ścisłych i przyrodniczych. Z czasopism publikujących teksty o tematyce archiwalnej, oprócz Rocznika, obecne na portalu są: „Archeion” i „Studia Archiwalne”. Wydawnictwa poruszające zagadnienia historyczne reprezentują m.in. „Prace Historyczne”, „Rocznik Biblioteki Naukowej PAU i PAN”, „Studia Historiae Scientiarum”, „Studia Judaica”, „Studia z Dziejów Średniowiecza”, https://www.ejournals. eu/ (odczyt: 19.10.2021).

${ }^{7}$ Materiały opracowały A. Sokół i A. Warzecha, przy udziale K. Follprecht.

${ }^{8}$ Dzięki obecności na portalu każdy tekst publikowany w Roczniku ma zapewniony numer DOI. Dla wydań aktualnych numery nadawane są na bieżąco, dla tomów archiwalnych - w momencie publikacji tomu na portalu. 
leży dodać, że w ramach współpracy z Wydawnictwem UJ Redakcja Rocznika ma także możliwość wykonania badania antyplagiatowego tekstów przesyłanych przez autorów do publikacji ${ }^{9}$.

Aktualnie na Portalu Czasopism Naukowych udostępnione są t. 23-26 „Krakowskiego Rocznika Archiwalnego", a do końca b.r. Redakcja planuje przygotować do publikacji kolejne (w tym najnowszy, t. 27).

Zarówno uruchomienie nowej strony internetowej Rocznika, jak też publikacja zawartości czasopisma na Portalu Czasopism Naukowych mają na celu rozpowszechnianie informacji o „Krakowskim Roczniku Archiwalnym i udostępnianie jego wersji cyfrowych w sposób najszerszy z możliwych w dzisiejszym scyfryzowanym świecie, tj. w internecie. Dzięki tym działaniom są wdrażane międzynarodowe standardy promujące politykę darmowego otwartego dostępu (open access) do wyników badań naukowych.

\section{Aldona Warzecha \\ Archiwum Narodowe w Krakowie}

${ }^{9}$ Badanie jest wykonywane w systemie Crossref Similarity Check, z wykorzystaniem oprogramowania iThenticate (http://www.ithenticate.com, odczyt: 19.10.2021). Pierwsza analiza przy pomocy ww. narzędzia została przeprowadzona przez Redakcję dla tekstów planowanych do publikacji w t. 27 „Krakowskiego Rocznika Archiwalnego”. 